\title{
A Modified Method for Studying Behavioral Paradox of Antioxidants and Their Disproportionate Competitive Kinetic Effect to Scavenge the Peroxyl Radical Formation
}

\author{
Nusrat Masood, ${ }^{1}$ Kaneez Fatima, ${ }^{1}$ and Suaib Luqman ${ }^{1,2}$ \\ ${ }^{1}$ Molecular Bioprospection Department, Biotechnology Division, CSIR-Central Institute of Medicinal and Aromatic Plants, \\ Lucknow 226015, India \\ ${ }^{2}$ Academy of Scientific and Innovative Research (AcSIR), CSIR-Central Institute of Medicinal and Aromatic Plants, \\ Lucknow 226015, India
}

Correspondence should be addressed to Suaib Luqman; s.luqman@cimap.res.in

Received 15 August 2013; Accepted 24 November 2013; Published 5 February 2014

Academic Editors: M. Y. Arica, K. M. Botham, A. A. Iglesias, and A. Surguchov

Copyright (C) 2014 Nusrat Masood et al. This is an open access article distributed under the Creative Commons Attribution License, which permits unrestricted use, distribution, and reproduction in any medium, provided the original work is properly cited.

\begin{abstract}
We have described a modified method for evaluating inhibitor of peroxyl radicals, a well-recognized and -documented radical involved in cancer initiation and promotion as well as diseases related to oxidative stress and ageing. We are reporting hydrophilic and lipophilic as well as natural and synthetic forms of antioxidants revealing a diversified behaviour to peroxyl radical in a dosedependent manner $(1 \mathrm{nM}-10 \mu \mathrm{M})$. A simple kinetic model for the competitive oxidation of an indicator molecule (ABTS) and a various antioxidant by a radical (ROO ${ }^{\circ}$ ) is described. The influences of both the concentration of antioxidant and duration of reaction $(70 \mathrm{~min})$ on the inhibition of the radical cation absorption are taken into account while determining the activity. The induction time of the reaction was also proposed as a parameter enabling determination of antioxidant content by optimizing and introducing other kinetic parameters in 96-well plate assays. The test evidently improves the original PRTC (peroxyl radical trapping capacity) assay in terms of the amount of chemical used, simultaneous tracking, that is, the generation of the radical taking place continually and the kinetic reduction technique (area under curve, peak value, slope, and $V_{\max }$ ).
\end{abstract}

\section{Introduction}

Peroxyl radicals $\left(\mathrm{ROO}^{\circ}\right)$, the chain carrying analogs of perhydroxyl radical $\left(\mathrm{HOO}^{\circ}\right)$ where the $\mathrm{H}$ atom is replaced by an organic group $(\mathrm{R})$, are formed due to the oxidation of proteins and lipids [1-4]. Activation of neutrophil during oxidative stress related inflammation also produces peroxyl radicals $[5,6]$. They are stable (reduction potential $[+]$ $0.77-[+] 1.44 \mathrm{~V}$ ) and do not dissociate into oxygen because of the stable $\mathrm{C}-\mathrm{O}$ bond. Its formation depends on the concentration of oxygen and other reactants as well as the hydrophobic/hydrophilic environment in which the reaction occurs [7-9]. These radicals not only occur in a cell but also transpire in aquatic systems (lakes, rivers, streams, and oceans) and in atmosphere (water droplets). Such successive reactions involving free radicals in biological systems lead to many physiological and pathological progressions [10-18].
In study allied to human disease, lipid peroxidation is correlated with peroxyl radical arbitrated reaction $[7,19$, 20], induction of DNA damage by superoxide is additively boosted by peroxyl radicals which is implicated in modification of protein, lipid, and DNA cleavage, nevertheless arsenic-mediated ROS generation produces dimethylarsinic peroxyl radicals $[7,21]$. The peroxyl radical, besides playing an outstanding character in radicals dependent shabbiness of membranes and proteins, is also fretful in the pathogenesis of a number of human diseases and disorders involving autoxidation of lipids, inactivation of certain enzymes, cleavage of phosphodiester bond resulting in single and double strand breaks, oxidizing thymidine resulting in mutagenic 5 -methyl oxidation products, and causing transversion at deoxyguanosine [22-26]. Involvement of peroxyl radicals in carcinogenesis relevant to tumor initiation and promotion is well reported. Investigation related to cancer and redox 
TABLE 1: List of indicator molecule with analysis system/model system for assessing peroxyl radical.

\begin{tabular}{lc}
\hline Name & Reference \\
\hline Crocin & {$[28]$} \\
BODIPY 581/591 C11 & {$[29]$} \\
cis-Parinaric acid & {$[30]$} \\
Phycoerythrin & {$[31]$} \\
C-phycocyanin & {$[32]$} \\
Dichlorofluorescin & {$[33]$} \\
Luminescence/chemiluminescence of luminal & {$[34-36]$} \\
Pyrogallol red & {$[37]$} \\
Analysis of lipid hydroperoxides by HPLC & {$[38]$} \\
Malondialdehyde-thiobarbituric assay & {$[39,40]$} \\
Electron spin resonance, a spin-trapping technique & {$[41]$} \\
GC-MS & {$[42]$} \\
\hline
\end{tabular}

biology proved that diminutive consideration has been given to peroxyl radicals and family of oxygen centred free radicals [27]. Modest information has been demeanour for peroxyl reactions, in spite of its importance in anticancer irradiation therapy, neurodisorders, ischaemia, and other oxidative stress related diseases and disorders [28].

A number of ways have been utilized for averting the constant expression of peroxyl radicals generated by water soluble $2,2^{\prime}$ azobis (2-amidinopropane) dihydrochloride $(\mathrm{AAPH})$ or lipid soluble 2,2' -azobis 2, 4dimethylvaleronitrile (AMVN) $[28,29]$ and the interaction of peroxyl radicals with antioxidants/unknown compounds can be analyzed by an assortment of indicator molecule/model systems as given in Table 1 . These reported methods evaluate how the substrate protects a compound from being degraded by peroxyl radicals, using an array of molecules as reactive targets/analysis of end products by different techniques. We employed ABTS as target molecule to assess the reactivity of antioxidants towards AAPH/ABAP-derived peroxyl radical formation in an easy controlled mode at $37^{\circ} \mathrm{C}$ in aqueous media.

As depicted in Figure 1, there is a unimolecular decomposition of AAPH/ABAP resulting in the formation of two carbon-centred radicals and nitrogen; the former reacts with oxygen to produce peroxyl radicals. We have modified the method of Bartosz et al. (1998) [43] and developed a 96-well plate assay procedure in which decomposition of AAPH (the source of peroxyl and alkoxyl radicals generated at a defined rate in aqueous solution) was measured at $414 \mathrm{~nm}$ with ABTS forming a green colored complex. In addition to this juncture, the overall reaction depends on temperature, solvent form, time, and $\mathrm{pH}$, propped up by kinetic studies carried out with the help of spectrophotometric analysis, thus clarifying the paradox behaviour of a series of antioxidants (Table 2). We therefore have a simple high throughput access system and/or technique to identify and explore novel scavenger/inhibitor of peroxyl radicals.

\section{Materials and Methods}

2.1. Chemicals. $2,2^{\prime}$-Azobis(2-methylpropionamidine) dihydrochloride (AAPH) also known as 2,2' -azobis (2-amido propane) (ABAP), 2,2' azoino-bis(3-ethyl benzothiazoline-6sulfonic acid) diammoniumsalt (ABTS) 6-hydroxy-2,5,7,8tetramethylchroman-2-carboxylic acid (trolox), hydrogen peroxide $\left(\mathrm{H}_{2} \mathrm{O}_{2}\right)$, L-ascorbic acid, and dimethyl sulfoxide (DMSO) were purchased from Sigma Aldrich Chemical Company, USA, while butylated hydroxytoluene (BHT), tert-butylhydroquinone (TBHQ), tert-butyl hydroperoxide (tBHP), butylated hydroxyanisole (BHA), tocopherol, npropyl gallate, quercetin, and $\beta$-carotene were purchased from Himedia, India. Di-sodium hydrogen phosphate $\left(\mathrm{Na}_{2} \mathrm{HPO}_{4}\right)$, sodium dihydrogen phosphate $\left(\mathrm{NaH}_{2} \mathrm{PO}_{4}\right)$, ethanol, methanol, and acetone were purchased from Merck India Ltd. All the chemicals, solvents and reagents used were either of analytical grade or higher.

2.2. Experimental. Stock solution of $0.1 \mathrm{M}$ sodium phosphate buffer ( $\mathrm{pH}$ 7.0) was made by mixing solutions of $\mathrm{Na}_{2} \mathrm{HPO}_{4}$ $(0.1 \mathrm{M})$ and $\mathrm{NaH}_{2} \mathrm{PO}_{4}(0.1 \mathrm{M})$ while stock solution of ABTS $(5 \mathrm{mM})$ and AAPH $(200 \mathrm{mM})$ was made in deionized water. $10 \mathrm{mM}$ stock solution of tBHP, BHT, L-ascorbic acid, trolox, nicotinic acid, and hydrogen peroxide was made in deionized water, tocopherol, $\mathrm{BHA}$ and n-propyl gallate was made in ethanol, TBHQ in methanol, quercetin in DMSO, and $\beta$ carotene in acetone. Dilution was done in $0.1 \mathrm{M}$ sodium phosphate buffer. The concentrations used for the analysis were $100 \mu \mathrm{M}, 10 \mu \mathrm{M}, 1 \mu \mathrm{M}, 0.1 \mu \mathrm{M}, 0.01 \mu \mathrm{M}$, and $0.001 \mu \mathrm{M}$.

Colorimetric peroxyl radical averting assay (PRAA) was done following method described by Bartosz et al. (1998) [43] with modification including increase in the time period from $10 \mathrm{~min}$ to $70 \mathrm{~min}$ and reduction in the volume of the reaction cocktail by 20 times. The additional feature of the modified method comprises kinetic reduction technique (area under curve, peak value, slope, time of half maximum, mean, and $\left.V_{\max }\right)$. Total reaction volume $(150 \mu \mathrm{L})$ of the modified method in 96-well plate contains $15 \mu \mathrm{L}$ of samples (10x), $15 \mu \mathrm{L}$ AAPH $(200 \mathrm{mM}), 4.5 \mu \mathrm{L}$ ABTS $(5 \mathrm{mM})$, and rest phosphate buffer. The phosphate buffer was preheated to $37^{\circ} \mathrm{C}$ for $30 \mathrm{~min}$ followed by the addition of other components including AAPH (source of peroxyl radical) added at the last and the absorbance was taken at $414 \mathrm{~nm}$ in a kinetic mode by presetting the spectrophotometer at $37^{\circ} \mathrm{C}$ for $0-70 \mathrm{~min}$. From the kinetic curve, time-dependent increase in the absorbance was read for each compound along with control. Appropriate solvent blank was run in each assay.

2.3. Assay Validation, Data Scrutiny, and Statistical Analysis. Data represented are mean/average \pm standard deviation of three independent experiments in duplicate. $\mathrm{IC}_{50}$ values were calculated from dose-responsive curve by using Table Curve 2D Windows version 4.07 (SPSS Inc., Chicago, IL, USA). Using the advanced kinetic reduction technique available in SoftMax Pro Microplate Data Acquisition and Analysis Software Version 5.3 (Molecular Devices Corporation, Sunnyvale CA, USA) various kinetic parameters were calculated: 
<smiles>CC=CN(C)C(C)(N)N=NC(C)(N)C(=N)N</smiles><smiles>CC(C)(C)C(=N)N</smiles>

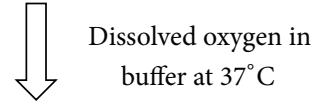<smiles>CC(N)C(=N)O[OH+]O[O-]</smiles>
AAPH peroxyl radical

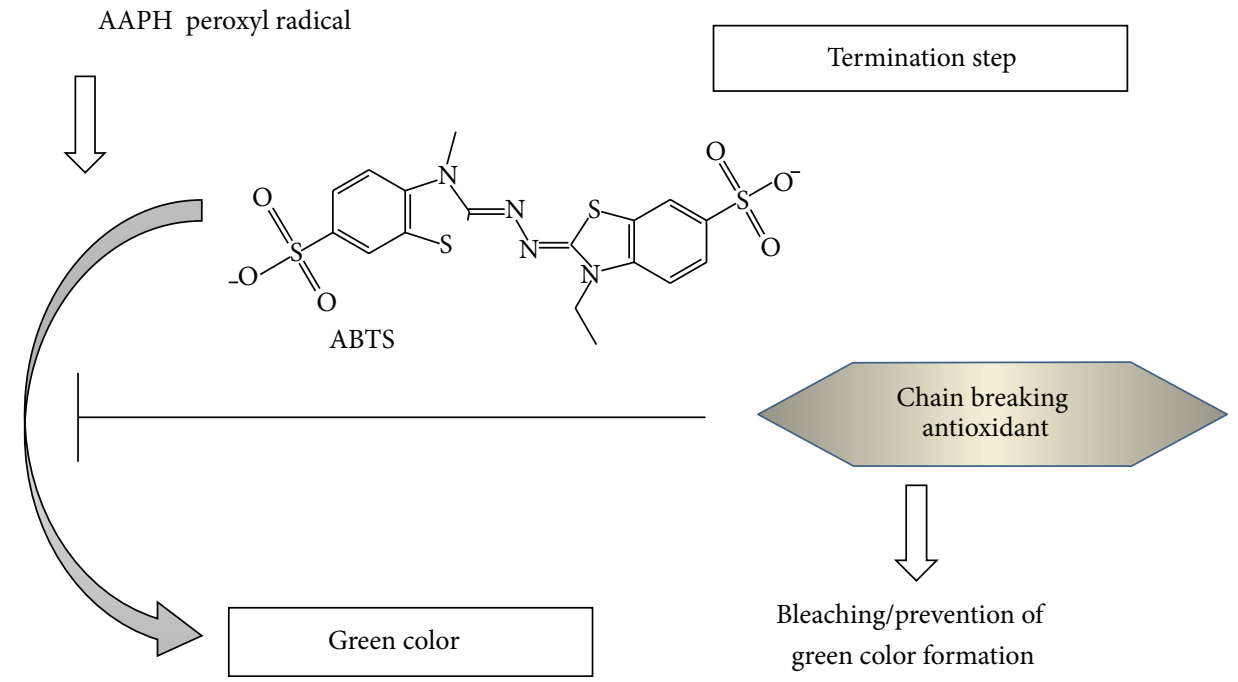

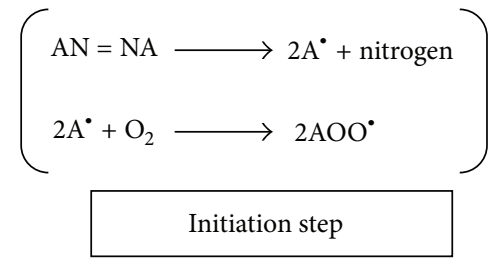

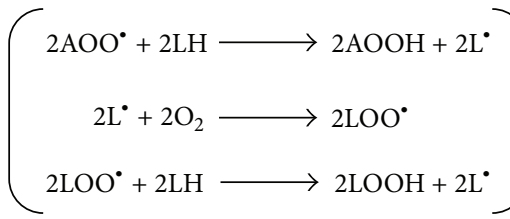

Propagation step

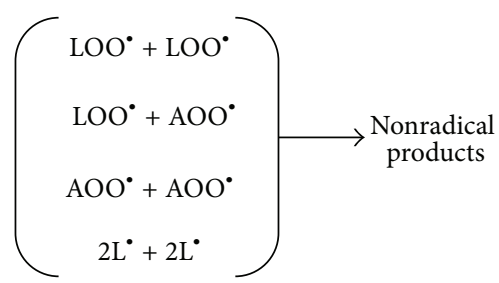

Figure 1: Decomposition of AAPH/ABAP and formation of Peroxyl radicals.

TABLE 2: Properties of the compound studied.

\begin{tabular}{|c|c|c|c|c|c|c|}
\hline Name & Pubchem ID & Molecular formula & Molecular weight $(\mathrm{g} / \mathrm{mol})$ & XLogP3- & H-bond donor & H-bond acceptor \\
\hline Trolox & 4063 & $\mathrm{C}_{14} \mathrm{H}_{18} \mathrm{O}_{4}$ & 250.29032 & AA: 2.8 & 2 & 4 \\
\hline$\alpha$-Tocopherol & 14985 & $\mathrm{C}_{29} \mathrm{H}_{50} \mathrm{O}_{2}$ & 430.7061 & AA: 10.7 & 1 & 2 \\
\hline Nicotinic acid & 982 & $\mathrm{C}_{6} \mathrm{H}_{5} \mathrm{NO}_{2}$ & 123.11 & 0.4 & 1 & 3 \\
\hline$\beta$ Carotene & 5280489 & $\mathrm{C}_{40} \mathrm{H}_{56}$ & 536.87264 & 13.5 & 0 & 0 \\
\hline Ascorbic acid & 54670067 & $\mathrm{C}_{6} \mathrm{H}_{8} \mathrm{O}_{6}$ & 176.12412 & -1.6 & 4 & 6 \\
\hline Quercetin & 5280343 & $\mathrm{C}_{15} \mathrm{H}_{10} \mathrm{O}_{7}$ & 302.24 & 1.5 & 5 & 7 \\
\hline n-Propyl gallate & 4947 & $\mathrm{C}_{10} \mathrm{H}_{12} \mathrm{O}_{5}$ & 212.19928 & 1.8 & 3 & 5 \\
\hline BHA & 8456 & $\mathrm{C}_{11} \mathrm{H}_{16} \mathrm{O}_{2}$ & 180.24354 & 3.2 & 1 & 2 \\
\hline BHT & 31404 & $\mathrm{C}_{15} \mathrm{H}_{24} \mathrm{O}$ & 220.35046 & AA: 5.3 & 1 & 1 \\
\hline TBHQ & 16043 & $\mathrm{C}_{10} \mathrm{H}_{14} \mathrm{O}_{2}$ & 166.21696 & 2.8 & 2 & 2 \\
\hline tBHP & 6410 & $\mathrm{C}_{4} \mathrm{H}_{10} \mathrm{O}_{2}$ & 90.121 & AA: 0.6 & 1 & 2 \\
\hline Hydrogen peroxide & 784 & $\mathrm{H}_{2} \mathrm{O}_{2}$ & 34.01468 & -0.9 & 2 & 2 \\
\hline
\end{tabular}


percent values for $V_{\max }$ (milli OD/min), peak, slope, and time of half maximum, mean, and area under curve using the formula: ((Control - Unknown)/Control*100). Pearson and RSQ values were also calculated for different parameters at higher tested concentration.

\section{Results and Discussion}

In the present work, a competitive kinetic method using ABTS as an indicator molecule was employed to estimate the reactivity of antioxidants towards AAPH/ABAP-derived peroxyl radical formation. The results obtained indicate that the relative protection afforded by a given compound strongly depends upon the experimental conditions employed and emphasize the role of secondary reactions of the phenolderived radicals initially formed. Herein we are reporting hydrophilic and lipophilic as well as natural and synthetic forms of antioxidants revealing a diversified behaviour to peroxyl radical in a dose-dependent manner $(1 \mathrm{nM}-10 \mu \mathrm{M})$. Hydrogen peroxide and tert-butyl hydroperoxide were used as checks. The influence of concentration of the antioxidants, duration of reaction system, and inhibition of the radical (cation or structure of antioxidant) absorption were taken into account while determining the scavenging potential.

Figures 2(a)-2(l) were plotted with control which showed a linear gradient in absorbance (optical density) from 0.06 to 0.6 within $70 \mathrm{~min}$ at $414 \mathrm{~nm}$ which gradually reaches maximum $(0.8-1.0)$ in $24 \mathrm{~h}$. The time period of $70 \mathrm{~min}(10$ time increase in OD) was chosen in order to get a clear picture of the compound which was not apparent in $10 \mathrm{~min}$ incubation time. For $\mathrm{IC}_{50}$ calculation, the percent scavenging value of $V_{\max }$ (milli absorbance/min) was chosen over the lag time period earlier reported to determine the scavenging capacity. It is evident from our plotted curves that not only lag time period but other features should also be considered while evaluating the ability of a particular compound as an effective scavenger of peroxyl radicals. The behaviour of the compounds varies which can be manifested by the graph not following the pattern of the control and the echelon of the offtrack hints the individual ability of both concentration and time-dependent.

A comprehensible concentration-dependent ( $1 \mathrm{nM}-$ $10 \mu \mathrm{M})$ diminishing interaction with peroxyl radical was observed in trolox (Figure 2(a)). Maximum kinetic inhibition was detected at $10 \mu \mathrm{M}$ and percent inhibition (in terms of $V_{\max }$, milli absorbance/min) was found to be in the range of -8.2 to 67.2 proving it as an effective scavenger of peroxyl radical formation in a dose-dependent manner. Trolox, a cell-permeable, water soluble imitative of vitamin $\mathrm{E}$ with compelling antioxidant assets [44, 45], is frequently used as a standard or positive control in antioxidant assays. It is also used to gauge the job of oxidative injury in cell death and ageing $[46,47]$ and as an effective therapy in the treatment of certain cancers [48]. Noteworthy effect was monitored in $\alpha$-tocopherol (Figure 2(b)) at $10 \mu \mathrm{M}$ and $1 \mu \mathrm{M}$ concentration. Percent inhibition was found to be in the range of -8.0 to 81.5 compared to control. $\alpha$-Tocopherol is the most imperative (90\%) among eight natural tocopherol, as peroxyl radicals scavenger/repressor of lipid peroxidation. Mechanistic study reveals that hydrogen atom is abstracted from the $\mathrm{OH}$ group in $\alpha$-tocopherol by a lipid peroxyl radical $\left[\mathrm{AOO}^{\circ}\right]$ producing fairly inert tocopheroxyl radical $\left[\mathrm{TocO}^{\bullet}\right]$, which may then react with a second radical [AOO $\left.{ }^{\bullet}\right]$ to yield a nonradical product, AOO-Toc, thus destroying two radicals and terminating the radical chain reactions thereby contributing two electrons as a chain breaking antioxidant [49]. Inspite of scavenging peroxyl radicals, they are unable to act as a potent scavenger of hydroxyl, alkoxyl, nitrogen dioxide, and thiyl radicals in vivo [50]. Behaviour of nicotinic acid (NA) was uncanny till $40 \mathrm{~min}$ and afterwards trifling scavenging started with time (Figure 2(c)). Percent inhibition was found to be in the range of -6.1 to 37.4 as the concentration increases from $1 \mathrm{nM}$ to $10 \mu \mathrm{M}$. NA, a colorless, water soluble derivative of pyridine with a carboxyl group at the 3-position, is a cofactor for NAD and NADP acting as coenzymes for more than thousand hydrogenases involved in almost every aspect of cell metabolism $[51,52]$. Additionally, it also reduces LDL, VLDL-C, and triglycerides but effectively increases HDL [53] and affects vascular endothelial oxidative and inflammatory events [54]. Much litigious $\beta$-carotene showed good scavenging effect at $10 \mu \mathrm{M}$ while at other concentrations the effect was equivalent to basal values (Figure 2(d)). Percent inhibition was found to be in the range of -4.4 to 40.5 . Belonging to carotenoid family, $\beta$-carotene also known as provitamin $\mathrm{A}$ has an unsaturated and long aliphatic hydrocarbon chain ultimately splitting into two molecules of vitamin A. Unlike phenolic antioxidants, they do not have reactive hydrogen to contribute to radicals, which make it difficult to use conventional probes for the assessment of their radical scavenging capacity [55]. Earlier investigators $[56,57]$ observed that it inhibits peroxyl radical-initiated autoxidation of both tetralin and methyl linoleate and it is more effective antioxidant at 15 torr oxygen concentration than at 150 torr. Others have noticed a reticent increase in its action against liposomes at 15 torr $[56,58]$ and at about 4 torr in microsomes $[56,59]$. $\beta$-Carotene eventually form a resonance-stabilized, carbon-centered radical adduct $\left[\mathrm{AOO}-\beta-\mathrm{C}^{*}\right]$. Interaction of second peroxyl radical to the adduct produces a nonradical product and results in an overall trapping of two peroxyl radicals per $\beta$-carotene consumed [56]. L-Ascorbic acid was found as an excellent scavenger at $10 \mu \mathrm{M}$ and $1 \mu \mathrm{M}$, an effect which decreases at lower concentrations (Figure 2(e)). Percent inhibition was found to be in the range of -2.5 to 97.7. Also known as vitamin $\mathrm{C}$, ascorbic acid is an important water soluble antioxidant in extracellular fluid present in its deprotonated state under most physiologic conditions [60-62]. It is effective scavenger of superoxide anion radical, hydrogen peroxide, hypochlorite, the hydroxyl radical, and peroxyl radicals [60, 63-69]. Comparatively, it is more effective in inhibiting lipid peroxidation initiated by a peroxyl radical than other human plasma components, such as protein thiols, urate, bilirubin, and $\alpha$-tocopherol [60, 70]. Ascorbic acid can also protect membranes against peroxidation by enhancing the action of tocopherol and thereby reestablishing the radical scavenging activity [60, 71-74]. Quercetin showed a preeminent scavenging of peroxyl radical formation both at 


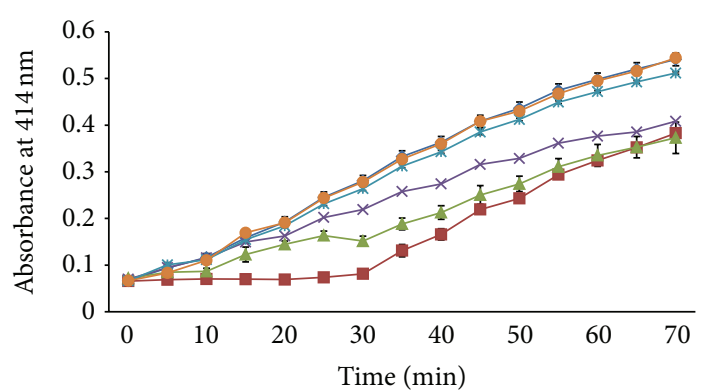

(a)

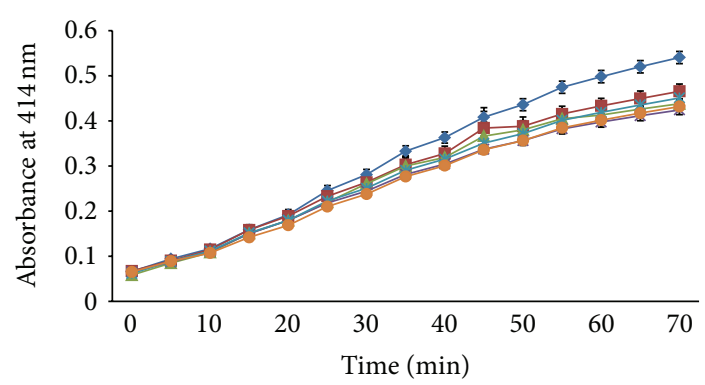

(c)

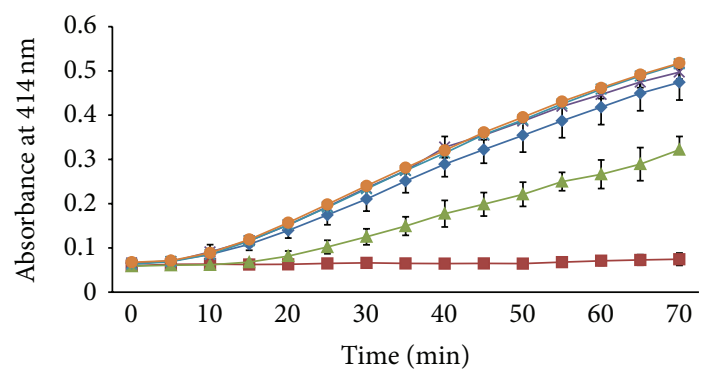

(e)

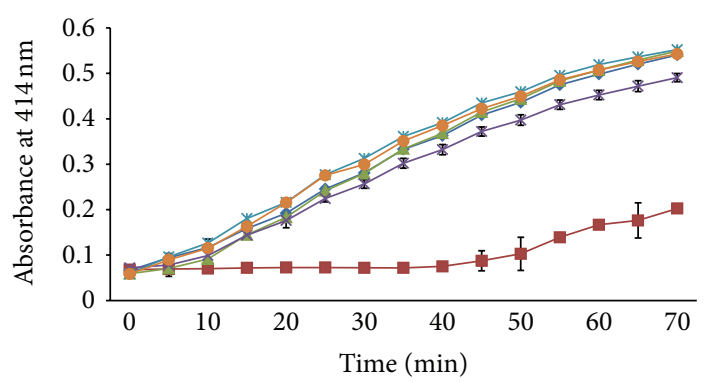

(g)

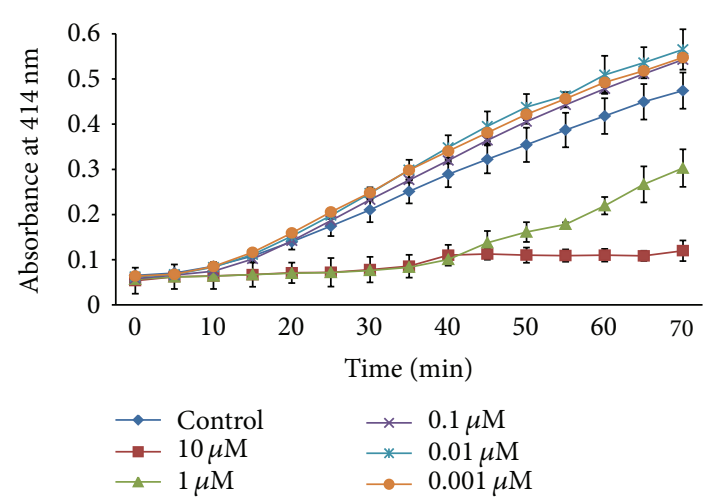

(i)

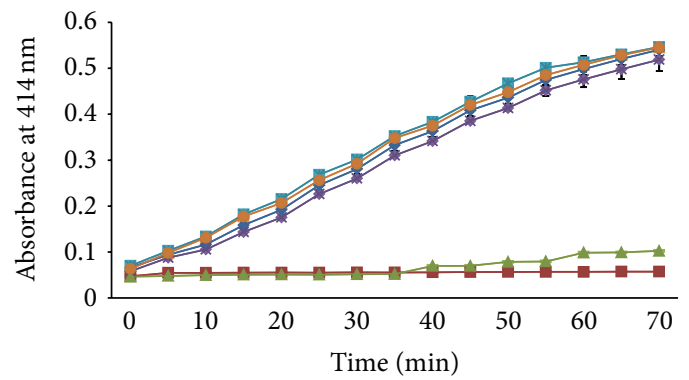

(b)

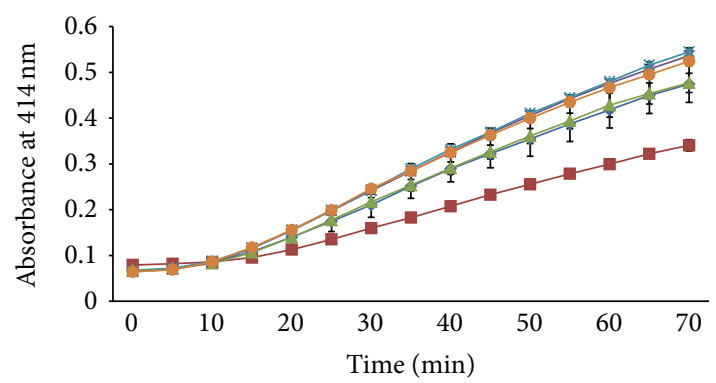

(d)

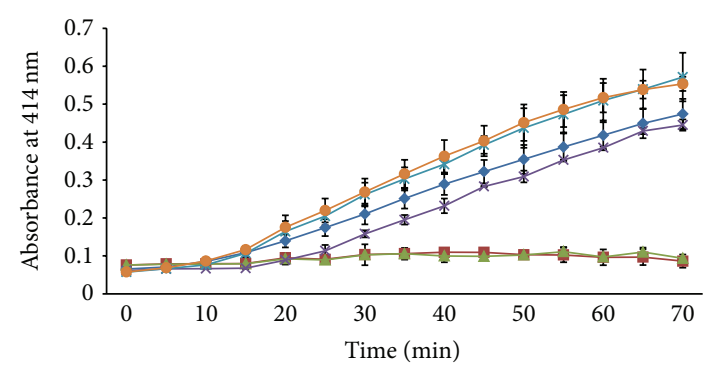

(f)

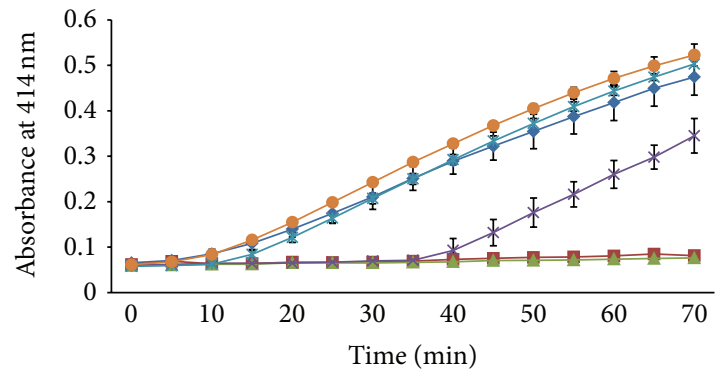

(h)

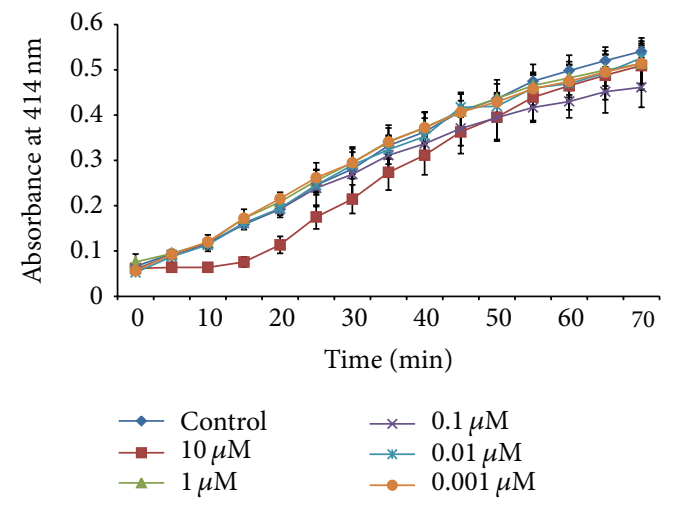

(j)

Figure 2: Continued. 


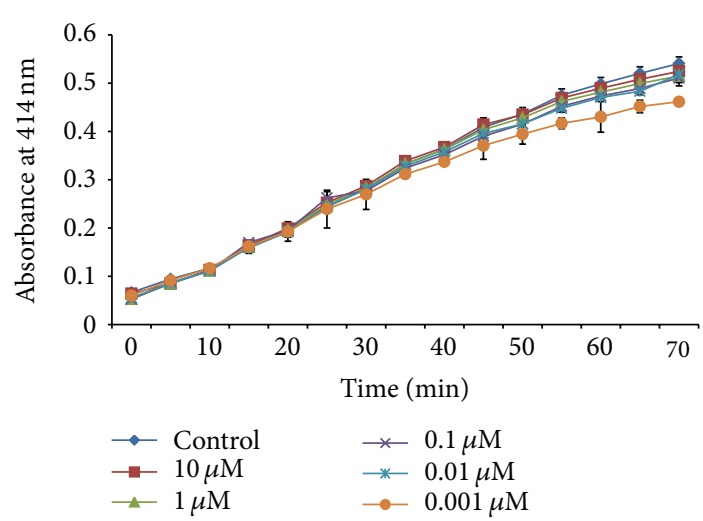

$(\mathrm{k})$

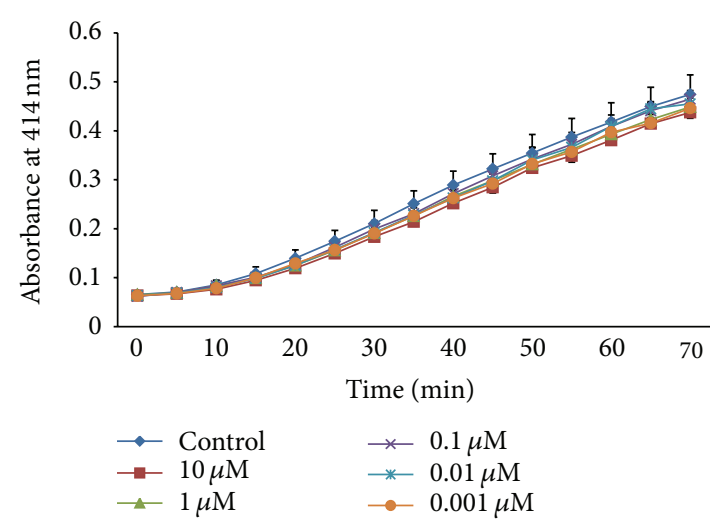

(l)

Figure 2: (a) Concentration-dependent peroxyl radical averting ability of trolox. (b) Concentration-dependent peroxyl radical averting ability of $\alpha$-tocopherol. (c) Concentration-dependent peroxyl radical averting ability of nicotinic acid. (d) Concentration-dependent peroxyl radical averting ability of $\beta$-carotene. (e) Concentration-dependent peroxyl radical averting ability of l-ascorbic acid. (f) Concentrationdependent peroxyl radical averting ability of quercetin. (g) Concentration-dependent peroxyl radical averting ability of $\mathrm{n}$-propyl gallate. (h) Concentration-dependent peroxyl radical averting ability of BHA. (i) Concentration-dependent peroxyl radical averting ability of BHT. (j) Concentration-dependent peroxyl radical averting ability of TBHQ. (k) Concentration-dependent peroxyl radical averting ability of tBHP. (l) Concentration-dependent peroxyl radical averting ability of $\mathrm{H}_{2} \mathrm{O}_{2}$.

$10 \mu \mathrm{M}$ and $1 \mu \mathrm{M}$ concentration (Figure $2(\mathrm{f})$ ) and the percent scavenging effect was found to be in the range of 11.48 to 98.3 in a concentration-dependent manner. It is a flavonoid phytochemical naturally occurring in the rind and bark of numerous plants. Chemically it is 2-(3,4-dihydroxyphenyl)3,5,7-trihydroxy-4H-1-benzopyran-4-one where B-ring is the active center for scavenging and stabilizing the free radicals [75-77]. Best effect of averting action of peroxyl radical by $\mathrm{n}$-propyl gallate was detected at $10 \mu \mathrm{M}$ with marginal to no scavenging was found at $0.1 \mu \mathrm{M}, 1 \mu \mathrm{M}, 10 \mathrm{nM}$, and $1 \mathrm{nM}$ concentration (Figure $2(\mathrm{~g})$ ). Percent averting action was found to be in the range of 17.17 to 79.57 . Propyl gallate, obtained from natural gallic acid (3,4,5-trihydroxybenzoic acid, $\left.\mathrm{C}_{6} \mathrm{H}_{2}(\mathrm{OH})_{3} \mathrm{COOH}\right)$, is one of the most effective antioxidant-based antimicrobials for the food industry. It has two functional groups hydroxyl and carboxyl and its two analogues were more effective than trolox in preventing cell lysis of human erythrocytes induced by peroxyl radical initiator [78]. Butylated hydroxyanisole (BHA) and butyl hydroxytoluene (BHT) are synthetic antioxidants exhibiting diverse effect. Significant inhibition was observed at $10 \mu \mathrm{M}$ and $1 \mu \mathrm{M}$ which decreases at lower dose (Figures 2(h) and 2(i)). Percent inhibition was found to be in the range of 23.75 to 96.6 and -10.9 to 96.2 for BHA and BHT, respectively. BHA consists of a mixture of two isomeric organic compounds, 2-tert-butyl-4-hydroxyanisole and 3-tert-butyl-4-hydroxyanisole. It is a waxy solid used as a food additive (E320), as an antioxidant and preservative in food, food packaging, animal feed, cosmetics, rubber, and petroleum products to prevent from rancidity and developing objectionable odors. It is also used in medicines, such as isotretinoin, lovastatin, and simvastatin [79]. BHT is a lipophilic organic compound which behaves as a synthetic analogue of vitamin E, primarily acting as a terminating agent that suppresses autoxidation by converting peroxyl radicals to hydroperoxides through donating a hydrogen atom [80]. $\mathrm{EC}_{50}$ value for $\mathrm{BHA}$ and $\mathrm{BHT}$ was found to be $18.94 \pm 0.38$ and $182.69 \pm 13.7 \mu \mathrm{M}$, respectively, in an ABAP generated peroxyl radicals, measured by inhibition of dichlorofluorescein oxidation [33]. Like BHT, the conjugated aromatic ring of $\mathrm{BHA}$ is able to stabilize free radicals through sequestration. Tertiary butylhydroquinone (TBHQ) flaunted good forestalling action at $10 \mu \mathrm{M}$ while fairly negligible effects were seen at other concentration (Figure 2(j)). Percent inhibition was found to be in the range of 19.97 to 61.37 in a concentration-dependent manner. TBHQ, a derivative of hydroquinone, substituted with tert-butyl group reacts with peroxyl radicals to form a semiquinone resonance hybrid which undergo different reactions to form more stable products reacting with one another to form dimers, dismutate, and regenerate as semiquinones before finally counteracting with another peroxy radical [81]. Interaction with peroxyl radicals exhibited no effect with tert-butyl hydroperoxide (Figure 2(k)) and hydrogen peroxide (Figure 2(l)). Both tert-butyl hydroperoxide $(\mathrm{tBuOOH} / \mathrm{tBHP})$ and hydrogen peroxide $\left(\mathrm{H}_{2} \mathrm{O}_{2}\right)$ were used as check compound for seeing the effect in peroxyl radical formation. $\mathrm{tBuOOH} / \mathrm{tBHP}$ used in a variety of oxidation processes depletes GSH, induces lipid peroxidation, and tempts ROS formation, involved in PLA(2) activation in hepatocyte injury [82], responsible for $\mathrm{K}^{+}$leakage [83]. Hydrogen peroxide $\left(\mathrm{H}_{2} \mathrm{O}_{2}\right)$ is a potent oxidant and is even more toxic to cells than superoxide radicals removed by enzymes, such as catalase, glutathione peroxidases, and cysteinyl peroxidase [49].

Antioxidants deactivate free radicals either by reduction via electron or by hydrogen atom. The end point result is the same regardless of the mechanism but the kinetics differ. For kinetic analysis we have used software in which kinetic data reduction options were present. We tried different 
TABLE 3: $\mathrm{IC}_{50}$ values and lag time of the compounds in peroxyl radical averting assay.

\begin{tabular}{lccc}
\hline Name & $\mathrm{IC}_{50}(\mu \mathrm{M})$ & Lag time $(\mathrm{min})$ & Concentration \\
\hline Trolox & 0.119 & 30 & $10 \mu \mathrm{M}$ \\
$\alpha$-Tocopherol & 0.289 & 35 & $1 \mu \mathrm{M}$ \\
Nicotinic acid & $\mathrm{ND}$ & $\mathrm{ND}$ & $\mathrm{ND}$ \\
$\beta$-Carotene & 91.95 & 15 & $10 \mu \mathrm{M}$ \\
Ascorbic acid & 1.38 & 15 & $1 \mu \mathrm{M}$ \\
Quercetin & 0.239 & 20 & $0.1 \mu \mathrm{M}$ \\
n-Propyl gallate & 5.8 & 45 & $10 \mu \mathrm{M}$ \\
BHA & 0.21 & 35 & $0.1 \mu \mathrm{M}$ \\
BHT & 0.885 & 40 & $1 \mu \mathrm{M}$ \\
TBHQ & 8.93 & 15 & $10 \mu \mathrm{M}$ \\
tBHP & $\mathrm{ND}$ & $\mathrm{ND}$ & $\mathrm{ND}$ \\
Hydrogen peroxide & $\mathrm{ND}$ & $\mathrm{ND}$ & $\mathrm{ND}$ \\
\hline
\end{tabular}

ND: not detected. Each data is mean average values of three independent experiments.

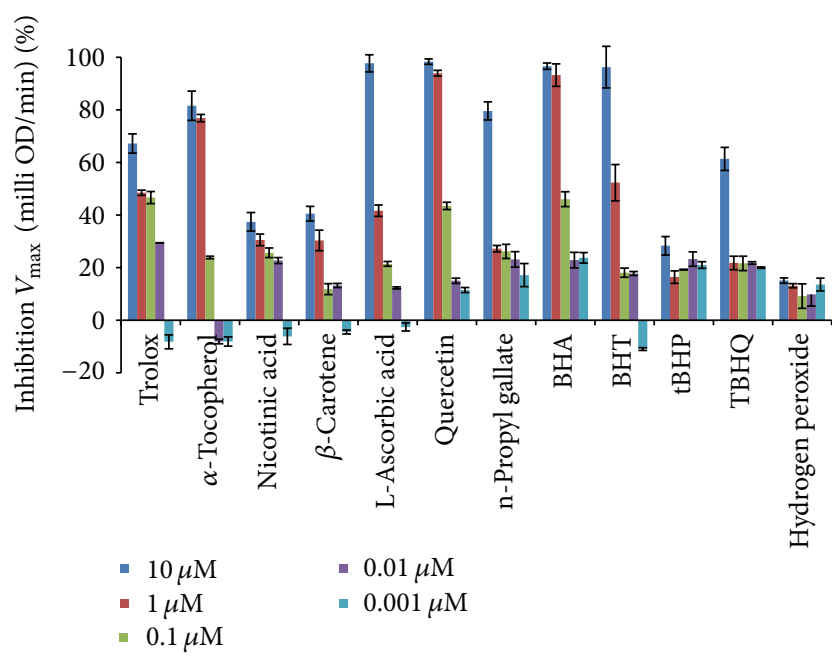

FIgURE 3: Percent inhibition calculated on the basis of $V_{\max }$ (mil$\mathrm{liOD} / \mathrm{min}$ ) of the kinetic curve.

options present to get a vivid picture of our experimental observations. All the kinetic parameters were calculated with respect to control as percent inhibition. The advantage of calculating using percent inhibition brought all kinetic parameters on the same platform in order to judge the kinetic behaviour characteristics independently. Percent inhibition of $V_{\max }$ (milli OD/min) of the kinetic curve was plotted for all twelve compounds (Figure 3 ) and $\mathrm{IC}_{50}$ values were calculated from table curve as given in Table 3. $V_{\max }$ is the maximum slope of the kinetic display of $\mathrm{mOD} / \mathrm{min}$, calculated by measuring the slopes of a number of straight lines, where $V_{\text {max }}$ points determine the number of contiguous points over which each straight line is defined. This is an alternative method for analyzing nonlinear kinetic reactions that reports the elapsed time until the maximum reaction rate is reached, rather than reporting the maximum rate itself. $V_{\max }$ rate is reported as signal/min (milli-OD/min) for a kinetic read. It is calculated using a linear curve fit, $y=A x+B$. A creeping iteration is performed using $V_{\max }$ points and the slope of the steepest line segment is reported as $V_{\max }$ rate. The first slope is calculated for a line drawn beginning at the first reading as defined by lag time and ending at a total number of readings equal to the $V_{\max }$ points setting. The second and any subsequent slopes are calculated beginning at the second time point and ending at a total number of readings. The steepest positive or negative slope is reported as $V_{\max }$. Decreasing order for the highest concentration used $(10 \mu \mathrm{M})$ is quercetin $>$ L-ascorbic acid $>$ BHA $>$ BHT $>\alpha$-tocopherol $>$ trolox $>$ TBHQ $>\beta$-carotene $>$ n-propyl gallate $>$ nicotinic acid $>$ $\mathrm{tBHP}>\mathrm{H}_{2} \mathrm{O}_{2}$.

Percent inhibition of area under curve is represented in Figure 4. Defined by the data within the reduction limits, plots are treated as a series of trapezoids with vertices at successive data points and at the $x$-axis coordinates of the data points. The areas defined by each of the trapezoids are then computed and summed. Order was found to be trolox $>$ quercetin $>$ n-propyl gallate $>\alpha$-tocopherol $>$ L-ascorbic acid $>\beta$ carotene $>$ BHA $>$ TBHQ $>$ nicotinic acid $>\mathrm{H}_{2} \mathrm{O}_{2}>$ tBHP $>$ BHT. Figure 5 signifies the percent slope (rate) of the time-dependent kinetics with respect to control. The slope reduction option determines the slope of the combined plot using all visible time points in the reduction window. Slope is the same as $V_{\max }$ rate when $V_{\max }$ rate is set to the same number of points as the run but is different if we have modified $V_{\max }$ points. Order noticed was trolox $>$ L-ascorbic acid $>$ BHA $>$ quercetin $>$ n-propyl gallate $>\alpha$-tocopherol $>$ nicotinic acid $>\beta$-carotene $>$ BHT $>$ tBHP $>$ TBHQ $>\mathrm{H}_{2} \mathrm{O}_{2}$.

Implication of the percent values with respect to control was also calculated on the basis of time to half maximum of the kinetic curve (Figure 6). It denotes half of maximum OD to the time that falls within the reduction limits. The software determines the kinetic point that has maximum OD, divided by 2 thus getting $1 / 2$ maximum values; further it finds the time at this $1 / 2$ maximum value. Order of the percent values was recorded as $\mathrm{BHT}>$ quercetin $>$ trolox $>$ TBHQ $>\mathrm{L}$ ascorbic acid $>$ nicotinic acid $>\alpha$-tocopherol $>$ tBHP $>$ BHA $>\mathrm{H}_{2} \mathrm{O}_{2}>\beta$ carotene $>n$-propyl gallate. Figure 7 designates percent mean values with respect to control, representing the average values (OD) generated during the specified time. 


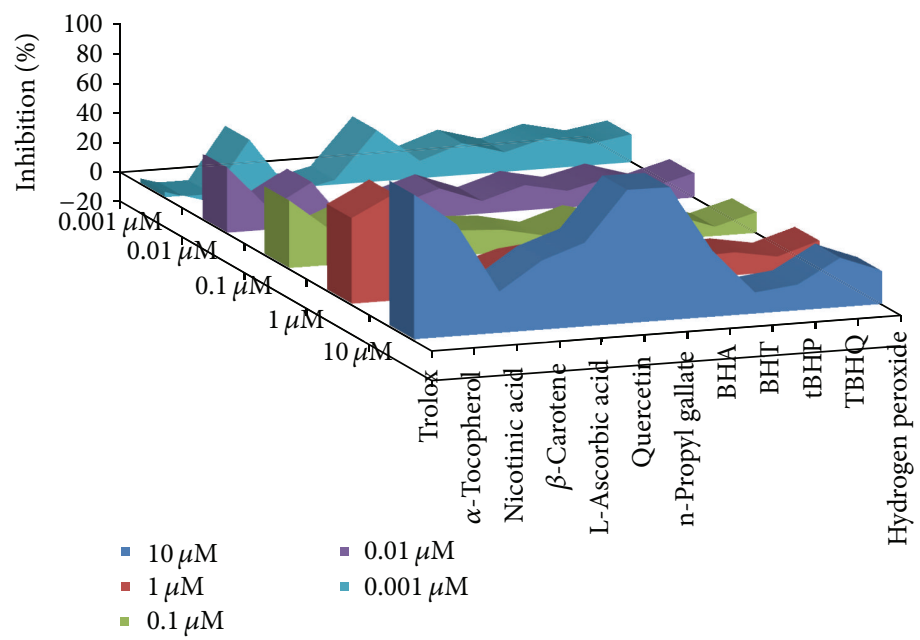

Figure 4: Percent area under curve with respect to control.

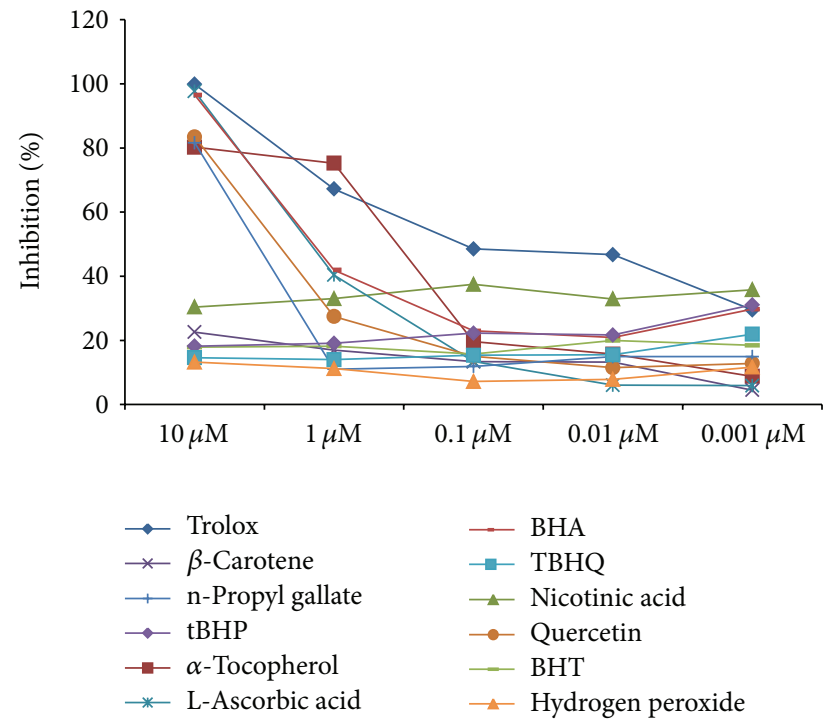

Figure 5: Percent slope (rate) of the time-dependent kinetics with respect to control.

Order was found to be BHT $>$ trolox $>$ L-ascorbic acid $>$ quercetin $>$ BHA $>$ TBHQ $>$ n-propyl gallate $>\alpha$-tocopherol $>\beta$-carotene $>$ nicotinic acid $>\mathrm{H}_{2} \mathrm{O}_{2}>$ tBHP. Figure 8 represents percent inhibition calculated from peak values of the kinetic data with respect to control, representing maximum absorbance of the compound at $414 \mathrm{~nm}$. Order was found to be $\mathrm{BHT}>$ trolox $>$ quercetin $>$ L-ascorbic acid $>$ $\mathrm{BHA}>\mathrm{TBHQ}>\mathrm{n}$-propyl gallate $>\alpha$-tocopherol $>$ nicotinic acid $>\beta$-carotene $>\mathrm{H}_{2} \mathrm{O}_{2}>$ tBHP. Pearson " $r$ " denotes the Pearson product moment correlation coefficient (Table 4). RSQ " $r 2$ " returns the square of the Pearson product moment correlation coefficient through the given data points. " $r 2$ " value is interpreted as the proportion of the variance in $y$ attributable to the variance in $x$, where $x$ and $y$ represent different parameters in sequence. " $r 2$ " is the square of this correlation coefficient presented in Table 5.

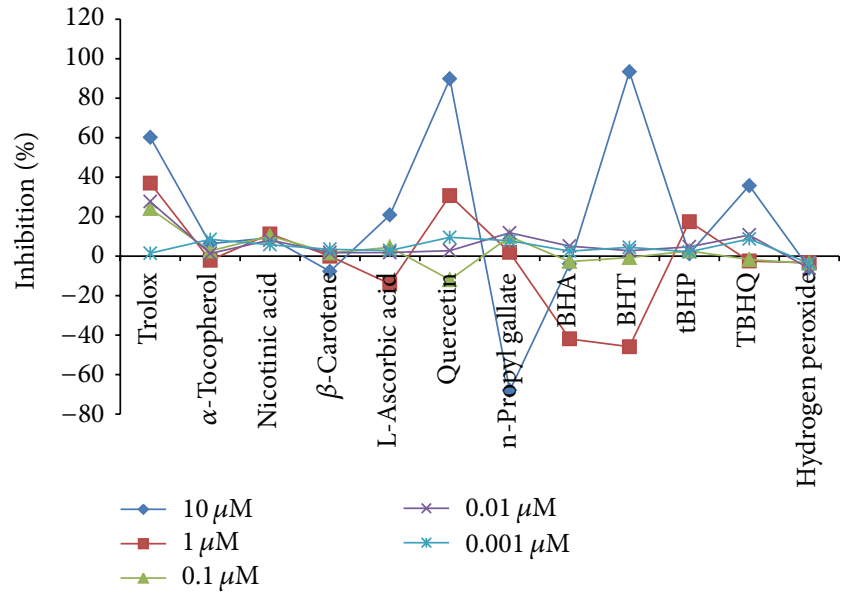

Figure 6: Percent values with respect to control calculated on the basis of time to half maximum of the kinetic curve.

\section{Conclusion}

Redox biology, an inescapable field known for its beneficial/detrimental property is being studied extensively. Radicals can wreak devastation on macromolecules/metabolites and may cause short/long term effects on cell signalling. Lipid peroxidation has been the issue of far-reaching scrutiny of mechanistic cell signalling and its involvement in human diseases/disorders. The development of a high-throughput absorbance assay for monitoring kinetics of peroxyl radical reactions in vitro is described in this paper where the evolution of the increase in absorbance values over time provides a rapid, facile method to conduct competitive kinetic studies in the presence of different antioxidants. A quantitative treatment formulated for the temporal evolution of the kinetic interpretation in terms of different parameters is presented. Combined, competitive kinetic assay and the data analysis provides a new method to obtain, in a rapid, parallel format, relative antioxidant capacity to retard the 
TABLE 4: Pearson values calculated for $10 \mu \mathrm{M}$ of various kinetic parameters.

\begin{tabular}{lcccccc}
\hline & $V_{\max }$ & Peak & Slope & Mean & $T:(1 / 2)$ max & 0.45 \\
\hline$V_{\max }$ & 1.00 & 0.95 & 0.67 & 0.97 & 0.97 & 0.36 \\
Peak & 0.95 & 1.00 & 0.63 & 1.00 & 0.63 & -0.01 \\
Slope & 0.67 & 0.63 & 0.63 & 1.00 & 0.39 & 0.54 \\
Mean & 0.97 & 0.97 & -0.01 & 0.39 & 1.00 & 0.54 \\
$T:(1 / 2) \max$ & 0.45 & 0.36 & 0.81 & 0.54 & -0.01 & 1.00 \\
Area & 0.54 & 0.54 & &
\end{tabular}

TABLE 5: RSQ values calculated for $10 \mu \mathrm{M}$ of various kinetic parameters.

\begin{tabular}{|c|c|c|c|c|c|c|}
\hline & $V_{\max }$ & Peak & Slope & Mean & $T:(1 / 2) \max$ & Area \\
\hline$\overline{V_{\max }}$ & 1.00 & 0.89 & 0.45 & 0.94 & 0.20 & 0.30 \\
\hline Peak & 0.89 & 1.00 & 0.40 & 0.94 & 0.13 & 0.30 \\
\hline Slope & 0.45 & 0.40 & 1.00 & 0.40 & 0.00 & 0.65 \\
\hline Mean & 0.94 & 0.94 & 0.40 & 1.00 & 0.15 & 0.29 \\
\hline$T:(1 / 2) \max$ & 0.20 & 0.13 & 0.00 & 0.15 & 1.00 & 0.00 \\
\hline Area & 0.30 & 0.30 & 0.65 & 0.29 & 0.00 & 1.00 \\
\hline
\end{tabular}

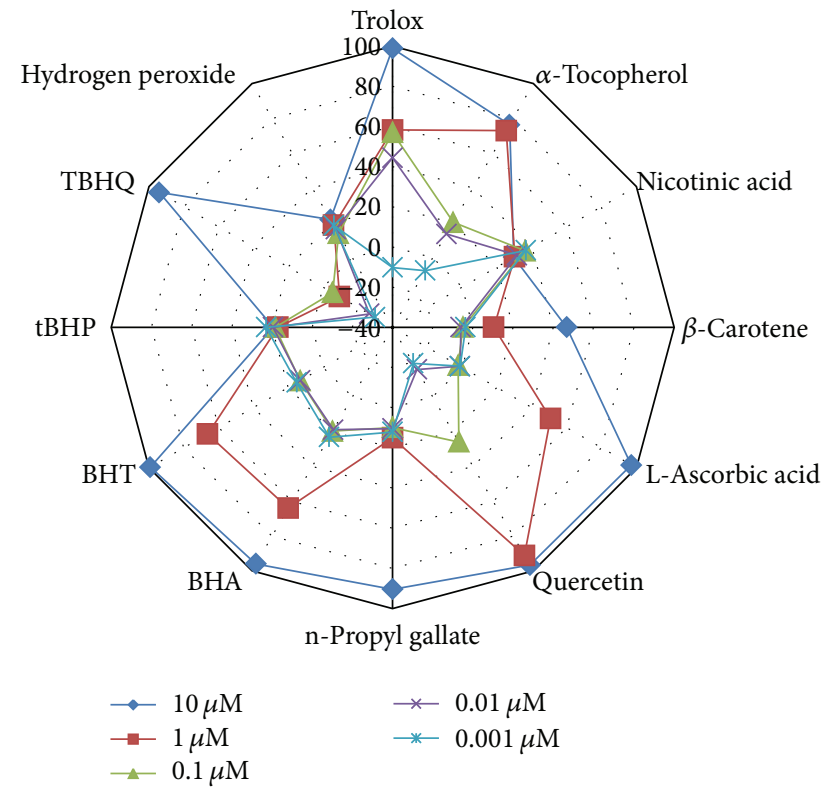

Figure 7: Percent mean values with respect to control. Mean values represent the average values (OD) generated during the time specified.

formation of peroxyl radicals. These data underpin the key role which the lipid environment plays in modulating the rate of reaction of antioxidants characterized by different inherent chemical reactivity/membrane mobility. The accuracy of these measurements depends mainly on the $\mathrm{pH}$ of buffer, solvent form, temperature, AAPH/ABAP and ABTS solution preparation. Amalgamation of AAPH/ABAP and ABTS is a highly accurate combination as ABTS solution does not react with the compounds in absence of AAPH/ABAP, is not light sensitive, and does not require sophisticated techniques. On the whole, this method with kinetic analysis part is a simple way of analyzing and interpreting character and behaviour of

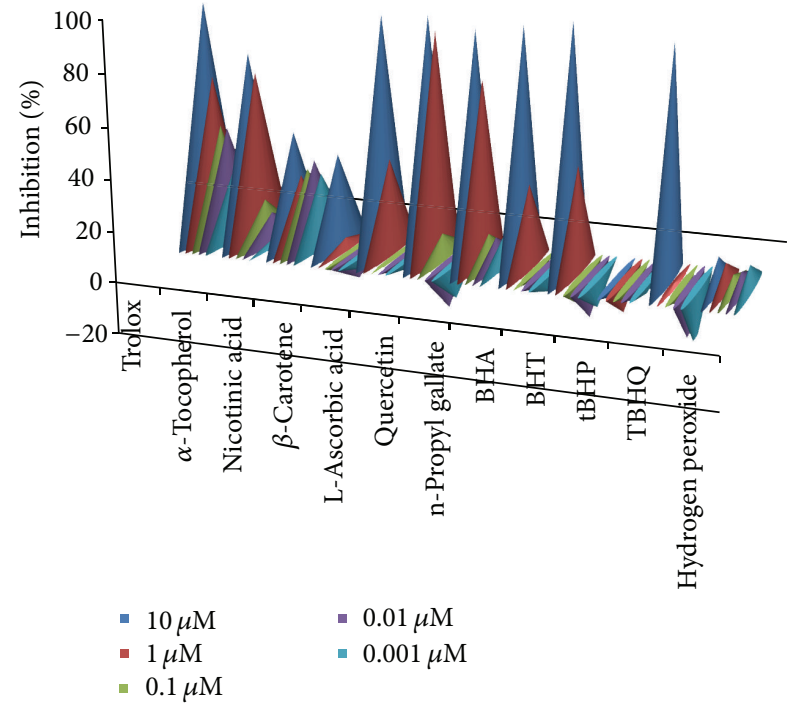

FIGURE 8: Percent inhibition is calculated from peak values of the kinetic data with respect to control. Peak values represent maximum OD of the compound at this wavelength.

the molecule. Altogether, a novel, facile method of study, new insights, and a quantitative understanding of the critical role in modulating peroxyl radical formation by antioxidants are reported.

\section{Conflict of Interests}

The authors declare no conflict of interests.

\section{Acknowledgments}

The authors are thankful to Council of Scientific and Industrial Research (CSIR), New Delhi, India, for a Senior 
Research Fellowship to the first author (Nusrat Masood) and financial assistance (BSC0121). Research work on plant based drug discovery in our laboratory is supported by Science and Engineering Research Board, Department of Science and Technology, Ministry of Science and Technology, Government of India, Council of Science and Technology, Government of Uttar Pradesh and Indian Council of Medical Research, New Delhi.

\section{References}

[1] L. J. Marnett, "Peroxyl free radicals: potential mediators of tumor initiation and promotion," Carcinogenesis, vol. 8, no. 10, pp. 1365-1373, 1987.

[2] M. Kappler, A. B. Gerry, E. Brown, L. Reid, D. S. Leake, and S. P. Gieseg, "Aqueous peroxyl radical exposure to THP-1 cells causes glutathione loss followed by protein oxidation and cell death without increased caspase-3 activity," Biochimica et Biophysica Acta, vol. 1773, no. 6, pp. 945-953, 2007.

[3] M. J. Davies, S. Fu, and R. T. Dean, "Protein hydroperoxides can give rise to reactive free radicals," Biochemical Journal, vol. 305, no. 2, pp. 643-649, 1995.

[4] U. P. Steinbrecher, S. Parthasarathy, D. S. Leake, J. L. Witztum, and D. Steinberg, "Modification of low density lipoprotein by endothelial cells involves lipid peroxidation and degradation of low density lipoprotein phospholipids," Proceedings of the National Academy of Sciences of the United States of America, vol. 81 , no. 12 , pp. 3883-3887, 1984.

[5] C. N. Oliver, "Inactivation of enzymes and oxidative modification of proteins by stimulated neutrophils," Archives of Biochemistry and Biophysics, vol. 253, no. 1, pp. 62-72, 1987.

[6] A. J. Kettle and C. C. Winterbourn, "Myeloperoxidase: a key regulator of neutrophil oxidant product," Redox Report, vol. 3, no. 1, pp. 3-15, 1997.

[7] M. Valko, C. J. Rhodes, J. Moncol, M. Izakovic, and M. Mazur, "Free radicals, metals and antioxidants in oxidative stressinduced cancer," Chemico-Biological Interactions, vol. 160, no. 1, pp. 1-40, 2006.

[8] P. C. Burcham, "Genotoxic lipid peroxidation products: their DNA damaging properties and role in formation of endogenous DNA adducts," Mutagenesis, vol. 13, no. 3, pp. 287-305, 1998.

[9] N. A. Porter, S. E. Caldwell, and K. A. Mills, "Mechanisms of free radical oxidation of unsaturated lipids," Lipids, vol. 30, no. 4, pp. 277-290, 1995.

[10] J. M. Gebicki, J. Collins, C. Gay, S. Duggan, and S. Gieseg, "The dissection of oxidative changes in human blood serum and U937 cells exposed to free radicals," Redox Report, vol. 5, no. 1, pp. 55-56, 2000.

[11] S. Gieseg, S. Duggan, and J. M. Gebicki, "Peroxidation of proteins before lipids in U937 cells exposed to peroxyl radicals," Biochemical Journal, vol. 350, no. 1, pp. 215-218, 2000.

[12] J. Du and J. M. Gebicki, "Proteins are major initial cell targets of hydroxyl free radicals," International Journal of Biochemistry and Cell Biology, vol. 36, no. 11, pp. 2334-2343, 2004.

[13] R. T. Dean, S. Fu, R. Stocker, and M. J. Davies, "Biochemistry and pathology of radical-mediated protein oxidation," Biochemical Journal, vol. 324, no. 1, pp. 1-18, 1997.

[14] J. A. Simpson, S. Narita, S. Gieseg, S. Gebicki, J. M. Gebicki, and R. T. Dean, "Long-lived reactive species on free-radicaldamaged proteins," Biochemical Journal, vol. 282, no. 3, pp. 621624, 1992.
[15] S. Gebicki and J. M. Gebicki, "Crosslinking of DNA and proteins induced by protein hydroperoxides," Biochemical Journal, vol. 338, no. 3, pp. 629-636, 1999.

[16] M. B. Hampton, P. E. Morgan, and M. J. Davies, "Inactivation of cellular caspases by peptide-derived tryptophan and tyrosine peroxides," FEBS Letters, vol. 527, no. 1-3, pp. 289-292, 2002.

[17] N. A. Porter, S. E. Caldwell, and K. A. Mills, "Mechanisms of free radical oxidation of unsaturated lipids," Lipids, vol. 30, no. 4, pp. 277-290, 1995.

[18] E. Niki, Y. Yoshida, Y. Saito, and N. Noguchi, "Lipid peroxidation: mechanisms, inhibition, and biological effects," Biochemical and Biophysical Research Communications, vol. 338, no. 1, pp. 668-676, 2005.

[19] J. M. C. Gutteridge, "Lipid peroxidation and antioxidants as biomarkers of tissue damage," Clinical Chemistry, vol. 41, no. 12, pp. 1819-1828, 1995.

[20] E. Cadenas and H. Sies, “The lag phase," Free Radical Research, vol. 28, no. 6, pp. 601-609, 1998.

[21] K. Yamanaka, F. Takabayashi, M. Mizoi, Y. An, A. Hasegawa, and S. Okada, "Oral exposure of dimethylarsinic acid, a main metabolite of inorganic arsenics, in mice leads to an increase in 8-oxo-2/-deoxyguanosine level, specifically in the target organs for arsenic carcinogenesis," Biochemical and Biophysical Research Communications, vol. 287, no. 1, pp. 66-70, 2001.

[22] K. U. Ingold, "Peroxy radicals," Accounts of Chemical Research, vol. 2, no. 1, pp. 1-9, 1969.

[23] L. J. Marnett, "Polycyclic aromatic hydrocarbon oxidation during prostaglandin biosynthesis," Life Sciences, vol. 29, no. 6, pp. 531-546, 1981.

[24] C. A. Gee, K. J. Kittridge, and R. L. Willson, "Peroxy free radicals, enzymes and radiation damage: sensitisation by oxygen and protection by superoxide dismutase and antioxidants," British Journal of Radiology, vol. 58, no. 687, pp. 251-256, 1985.

[25] M. Martini and J. Termini, "Peroxy radical oxidation of thymidine," Chemical Research in Toxicology, vol. 10, no. 2, pp. 234241, 1997.

[26] M. R. Valentine, H. Rodriguez, and J. Termini, "Mutagenesis by peroxy radical is dominated by transversions at deoxyguanosine: evidence for the lack of involvement of 8-oxo-dG1 and/or abasic site formation," Biochemistry, vol. 37, no. 19, pp. 70307038, 1998.

[27] L. Zennaro, M. Rossetto, P. Vanzani et al., "A method to evaluate capacity and efficiency of water soluble antioxidants as peroxyl radical scavengers," Archives of Biochemistry and Biophysics, vol. 462, no. 1, pp. 38-46, 2007.

[28] S. Lussignoli, M. Fraccaroli, G. Andrioli, G. Brocco, and P. Bellavite, "A microplate-based colorimetric assay of the total peroxyl radical trapping capability of human plasma," Analytical Biochemistry, vol. 269, no. 1, pp. 38-44, 1999.

[29] Y. M. A. Naguib, "A fluorometric method for measurement of peroxyl radical scavenging activities of lipophilic antioxidants," Analytical Biochemistry, vol. 265, no. 2, pp. 290-298, 1998.

[30] F. A. Kuypers, J. J. M. van den Berg, C. Schalkwijk, B. Roelofsen, and J. A. F. O. D. Kamp, "Parinaric acid as a sensitive fluorescent probe for the determination of lipid peroxidation," Biochimica et Biophysica Acta, vol. 921, no. 2, pp. 266-274, 1987.

[31] R. J. DeLange and A. N. Glazer, "Phycoerythrin fluorescencebased assay for peroxy radicals: a screen for biologically relevant protective agents," Analytical Biochemistry, vol. 177, no. 2, pp. 300-306, 1989. 
[32] E. A. Lissi, M. Pizarro, A. Aspee, and C. Romay, "Kinetics of phycocyanine bilin groups destruction by peroxyl radicals," Free Radical Biology and Medicine, vol. 28, no. 7, pp. 1051-1055, 2000.

[33] K. K. Adom and H. L. Rui, "Rapid peroxyl radical scavenging capacity (PSC) assay for assessing both hydrophilic and lipophilic antioxidants," The Journal of Agricultural and Food Chemistry, vol. 53, no. 17, pp. 6572-6580, 2005.

[34] T. Metsä-Ketelä, "Luminescent assay for total peroxyl radical trapping capability of plasma," in Bioluminescence and Chemiluminescence Current Status, P. E. Stanley and L. J. Kricka, Eds., pp. 389-392, Wiley \& Sons, Chichester, UK, 1991.

[35] E. Lissi, C. Pascual, and M. D. Del Castillo, "Luminol luminescence induced by $2,2^{\prime}$-Azo-bis(2-amidinopropane) thermolysis," Free Radical Research Communications, vol. 17, no. 5, pp. 299-311, 1992.

[36] H.-J. Freisleben and L. Packer, "Free-radical scavenging activities, interactions and recycling of antioxidants," Biochemical Society Transactions, vol. 21, no. 2, pp. 325-330, 1993.

[37] C. López-Alarcón and E. Lissi, "Interaction of pyrogallol red with peroxyl radicals. A basis for a simple methodology for the evaluation of antioxidant capabilities," Free Radical Research, vol. 39, no. 7, pp. 729-736, 2005.

[38] N. Noguchi, N. Gotoh, and E. Niki, "Dynamics of the oxidation of low density lipoprotein induced by free radicals," Biochimica et Biophysica Acta, vol. 1168, no. 3, pp. 348-357, 1993.

[39] T. F. Slater, "Overview of methods used for detecting lipid peroxidation," Methods in Enzymology, vol. 105, pp. 283-293, 1984.

[40] D. R. Janero, "Malondialdehyde and thiobarbituric acidreactivity as diagnostic indices of lipid peroxidation and peroxidative tissue injury," Free Radical Biology and Medicine, vol. 9, no. 6, pp. 515-540, 1990.

[41] B. Kalyanaraman, C. Mottley, and R. P. Mason, "A direct electron spin resonance and spin-trapping investigation of peroxyl free radical formation by hematin/hydroperoxide systems," The Journal of Biological Chemistry, vol. 258, no. 6, pp. 3855-3858, 1983.

[42] R. Lamrini, P. Lacan, A. Francina et al., "Oxidative decarboxylation of benzoic acid by peroxyl radicals," Free Radical Biology and Medicine, vol. 24, no. 2, pp. 280-289, 1998.

[43] G. Bartosz, A. Janaszewska, D. Ertel, and M. Bartosz, "Simple determination of peroxyl radical-trapping capacity," Biochemistry and Molecular Biology International, vol. 46, no. 3, pp. 519528, 1998.

[44] P. Cos, N. Hermans, M. Calomme et al., "Comparative study of eight well-known polyphenolic antioxidants," Journal of Pharmacy and Pharmacology, vol. 55, no. 9, pp. 1291-1297, 2003.

[45] B. Tadolini, C. Juliano, L. Piu, F. Franconi, and L. Cabrini, "Resveratrol inhibition of lipid peroxidation," Free Radical Research, vol. 33, no. 1, pp. 105-114, 2000.

[46] H. J. Jang, S. Hwang, K. Y. Cho, D. K. Kim, K.-O. Chay, and J.-K. Kim, "Taxol induces oxidative neuronal cell death by enhancing the activity of NADPH oxidase in mouse cortical cultures," Neuroscience Letters, vol. 443, no. 1, pp. 17-22, 2008.

[47] M. G. Benedetti, A. L. Foster, M. C. Vantipalli et al., "Compounds that confer thermal stress resistance and extended lifespan," Experimental Gerontology, vol. 43, no. 10, pp. 882-891, 2008.

[48] Z. Diaz, A. Laurenzana, K. K. Mann, T. A. Bismar, H. M. Schipper, and W. H. Miller Jr., "Trolox enhances the antilymphoma effects of arsenic trioxide, while protecting against liver toxicity," Leukemia, vol. 21, no. 10, pp. 2117-2127, 2007.
[49] R. Wolf, D. Wolf, and V. Ruocco, "Vitamin E: the radical protector," Journal of the European Academy of Dermatology and Venereology, vol. 10, no. 2, pp. 103-117, 1998.

[50] E. Niki, "Role of vitamin E as a lipid-soluble peroxyl radical scavenger: in vitro and in vivo evidence," Free Radical Biology Medicine, vol. 8, no. 66, pp. 3-12, 2014.

[51] P. Wan, S. Moat, and A. Anstey, "Pellagra: a review with emphasis on photosensitivity," British Journal of Dermatology, vol. 164, no. 6, pp. 1188-1200, 2011.

[52] N. Ishii and Y. Nishihara, "Pellagra among chronic alcoholics: clinical and pathological study of 20 necropsy cases," Journal of Neurology Neurosurgery and Psychiatry, vol. 44, no. 3, pp. 209215, 1981.

[53] T. C. Villines, A. S. Kim, R. S. Gore, and A. J. Taylor, "Niacin: the evidence, clinical use, and future directions," Current Atherosclerosis Reports, vol. 14, no. 1, pp. 49-59, 2012.

[54] V. S. Kamanna, S. H. Ganji, and M. L. Kashyap, "Recent advances in niacin and lipid metabolism," Current Opinion in Lipidology, vol. 24, no. 3, pp. 239-245, 2013.

[55] M. Takashima, M. Shichiri, Y. Hagihara, Y. Yoshida, and E. Niki, "Capacity of peroxyl radical scavenging and inhibition of lipid peroxidation by $\beta$-carotene, lycopene, and commercial tomato juice," Food Function, vol. 3, pp. 1153-1160, 2012.

[56] T. A. Kennedy and D. C. Liebler, "Peroxyl radical scavenging by $\beta$-carotene in lipid bilayers. Effect of oxygen partial pressure," The Journal of Biological Chemistry, vol. 267, no. 7, pp. 46584663, 1992.

[57] G. W. Burton and K. U. Ingold, " $\beta$-Carotene: an unusual type of lipid antioxidant," Science, vol. 224, no. 4649, pp. 569-573, 1984.

[58] R. Stocker, Y. Yamamoto, and A. F. McDonagh, "Bilirubin is an antioxidant of possible physiological importance," Science, vol. 235, no. 4792, pp. 1043-1046, 1987.

[59] G. F. Vile and C. C. Winterbourn, "Inhibition of adriamycinpromoted microsomal lipid peroxidation by $\beta$-carotene, $\alpha$ tocopherol and retinol at high and low oxygen partial pressures," FEBS Letters, vol. 238, no. 2, pp. 353-356, 1988.

[60] H. Sies and W. Stahl, "Vitamins E and C, $\beta$-carotene, and other carotenoids as antioxidants," The American Journal of Clinical Nutrition, vol. 62, no. 6, pp. 1315S-1321S, 1995.

[61] U. Moser and A. Bendich, "Vitamin C," in Handbook of Vitamins, U. Machlin, Ed., pp. 195-232, Marcel Dekker, New York, NY, USA, 1991.

[62] R. Stocke and B. Frei, "Endogenous antioxidant defense in human blood plasma," in Oxidative Stress: Oxidants and Antioxidants, H. Sies, Ed., pp. 213-243, Academic Press, London, UK, 1991.

[63] M. Nishikimi, "Oxidation of ascorbic acid with superoxide anion generated by the xanthine xanthine oxidase system," Biochemical and Biophysical Research Communications, vol. 63, no. 2, pp. 463-468, 1975.

[64] R. S. Bodannes and P. C. Chan, "Ascorbic acid as a scavenger of singlet oxygen," FEBS Letters, vol. 105, no. 2, pp. 195-196, 1979.

[65] D. E. Cabelli and B. H. J. Bielski, "Kinetics and mechanism for the oxidation of ascorbic acid/ascorbate by $\mathrm{HO} 2 / \mathrm{O} 2$ - radicals. A pulse radiolysis and stopped-flow photolysis study," The Journal of Physical Chemistry, vol. 87, no. 10, pp. 1809-1812, 1983.

[66] A. Bendich, U. MachIm, O. Scandurra, G. W. Burton, and D. D. M. Wayner, "The antioxidant role of vitamin C," Advances in Free Radical Biology and Medicine, vol. 2, no. 2, pp. 419-444, 1986. 
[67] B. Halliwell, M. Wasil, and M. Grootveld, "Biologically significant scavenging of the myeloperoxidase-derived oxidant hypochlorous acid by ascorbic acid. Implications for antioxidant protection in the inflamed rheumatoid joint," FEBS Letters, vol. 213, no. 1, pp. 15-17, 1987.

[68] A. Dwenger, M. Funck, B. Lueken, G. Schweitzer, and U. Lehmann, "Effect of ascorbic acid on neutrophil functions and Hypoxanthine/Xanthine Oxidase-Generated, oxygen-derived radicals," European Journal of Clinical Chemistry and Clinical Biochemistry, vol. 30, no. 4, pp. 187-191, 1992.

[69] B.-M. Kwon and C. S. Foote, "Chemistry of singlet oxygen. 50. Hydroperoxide intermediates in the photooxygenation of ascorbic acid," Journal of the American Chemical Society, vol. 110, no. 19, pp. 6582-6583, 1988.

[70] B. Frei, L. England, and B. N. Ames, "Ascorbate is an outstanding antioxidant in human blood plasma," Proceedings of the National Academy of Sciences of the United States of America, vol. 86, no. 16, pp. 6377-6381, 1989.

[71] E. Niki, A. Kawakami, Y. Yamamoto, and Y. Kamiya, “Oxidation of lipids. VIII. Synergistic inhibition of oxidation of phosphatidylcholine liposome in aqueous dispersion by vitamin $\mathrm{E}$ and vitamin C," Bulletin of the Chemical Society of Japan, vol. 58, no. 7, pp. 1971-1975, 1985.

[72] D. D. M. Wayner, G. W. Burton, K. U. Ingold, L. R. C. Barclay, and S. J. Locke, "The relative contributions of vitamin E, urate, ascorbate and proteins to the total peroxyl radical-trapping antioxidant activity of human blood plasma," Biochimica et Biophysica Acta, vol. 924, no. 3, pp. 408-419, 1987.

[73] T. Doba, G. W. Burton, and K. U. Ingold, "Antioxidant and coantioxidant activity of vitamin C. The effect of vitamin C, either alone or in the presence of vitamin $\mathrm{E}$ or a water-soluble vitamin E analogue, upon the peroxidation of aqueous multilamellar phospholipid liposomes," Biochimica et Biophysica Acta, vol. 835, no. 2, pp. 298-303, 1985.

[74] P. Lambelet, F. Saucy, and J. Loliger, "Chemical evidence for interactions between vitamins E and C," Experientia, vol. 41, no. 11, pp. 1384-1388, 1985.

[75] H.-Y. Zhang, L.-F. Wang, and Y.-M. Sun, "Why B-ring is the active center for genistein to scavenge peroxyl radical: a DFT study," Bioorganic and Medicinal Chemistry Letters, vol. 13, no. 5, pp. 909-911, 2003.

[76] W. Bors, W. Heller, C. Michel, and M. Saran, "Flavonoids as antioxidants: determination of radical-scavenging efficiencies," Methods in Enzymology, vol. 186, pp. 343-355, 1990.

[77] P. J. O'Malley, “The reaction profile for hydrogen atom transfer from phenol to peroxyl free radicals," Chemical Physics Letters, vol. 364, no. 3-4, pp. 318-322, 2002.

[78] J. Wu, H. Sugiyama, L.-H. Zeng, D. Mickle, and T.-W. Wu, "Evidence of Trolox and some gallates as synergistic protectors of erythrocytes against peroxyl radicals," Biochemistry and Cell Biology, vol. 76, no. 4, pp. 661-664, 1998.

[79] L. K. T. Lam, R. P. Pai, and L. W. Wattenberg, "Synthesis and chemical carcinogen inhibitory activity of 2-tert-butyl-4hydroxyanisole," Journal of Medicinal Chemistry, vol. 22, no. 5, pp. 569-571, 1979.

[80] G. W. Burton and K. U. Ingold, "Autoxidation of biological molecules. 1 . The antioxidant activity of vitamin $\mathrm{E}$ and related chain-breaking phenolic antioxidants in vitro," Journal of the American Chemical Society, vol. 103, no. 21, pp. 6472-6477, 1981.

[81] P. K. J. P.D. Wanasundara and F. Shahidi, "Antioxidants: science, technology, and applications," in Bailey's Industrial Oil and Fat
Products, F. Shahidi, Ed., pp. 431-489, John Wiley \& Sons, Hoboken, NJ, USA, 2005.

[82] C. Martín, R. Martínez, R. Navarro, J. I. Ruiz-Sanz, M. Lacort, and M. B. Ruiz-Larrea, "tert-Butyl hydroperoxide-induced lipid signaling in hepatocytes: involvement of glutathione and free radicals," Biochemical Pharmacology, vol. 62, no. 6, pp. 705-712, 2001.

[83] J. van der Zee, J. van Steveninck, J. F. Koster, and T. M. A. R. Dubbelman, "Inhibition of enzymes and oxidative damage of red blood cells induced by t-butylhydroperoxide-derived radicals," Biochimica et Biophysica Acta, vol. 980, no. 2, pp. 175180,1989 . 

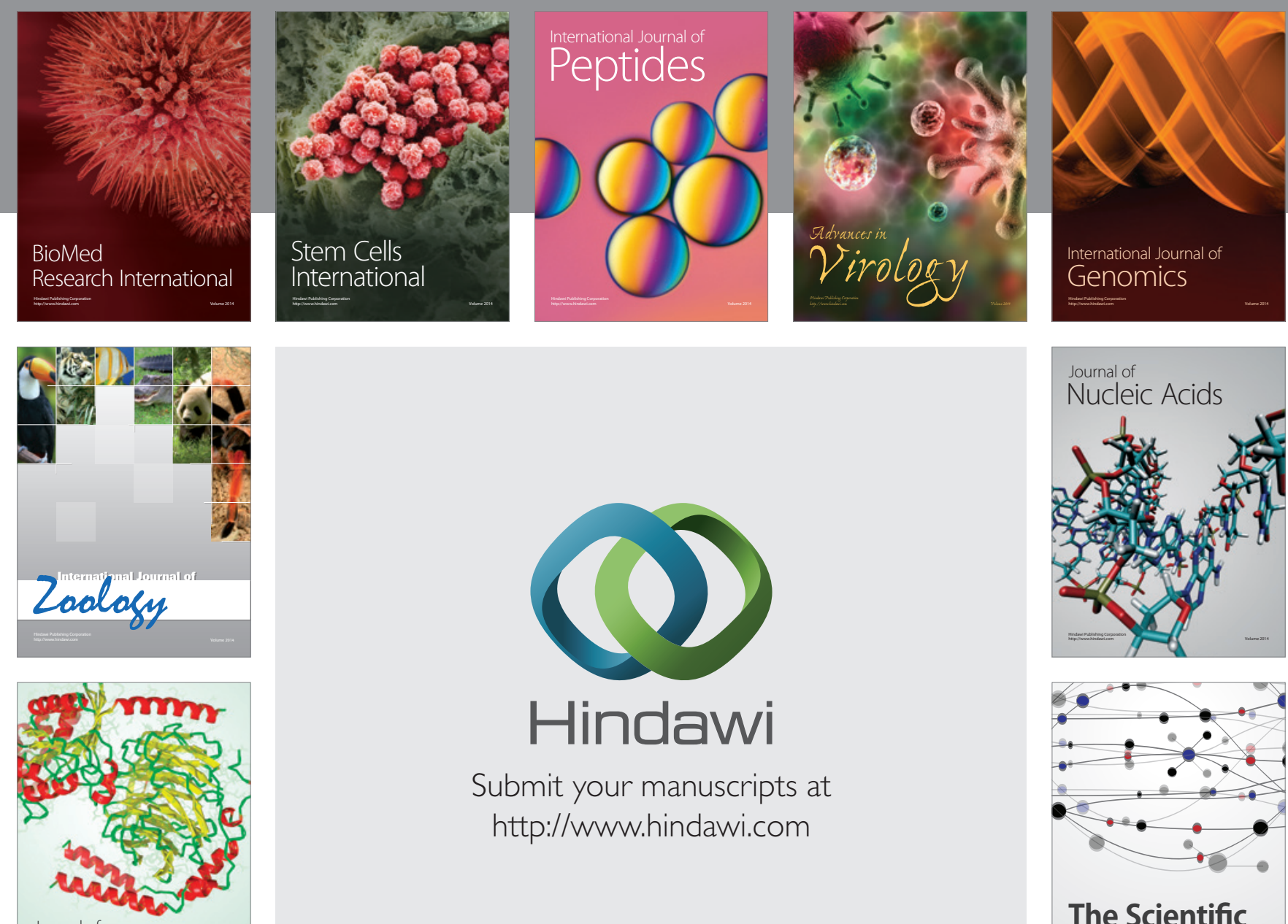

Submit your manuscripts at

http://www.hindawi.com

Journal of
Signal Transduction
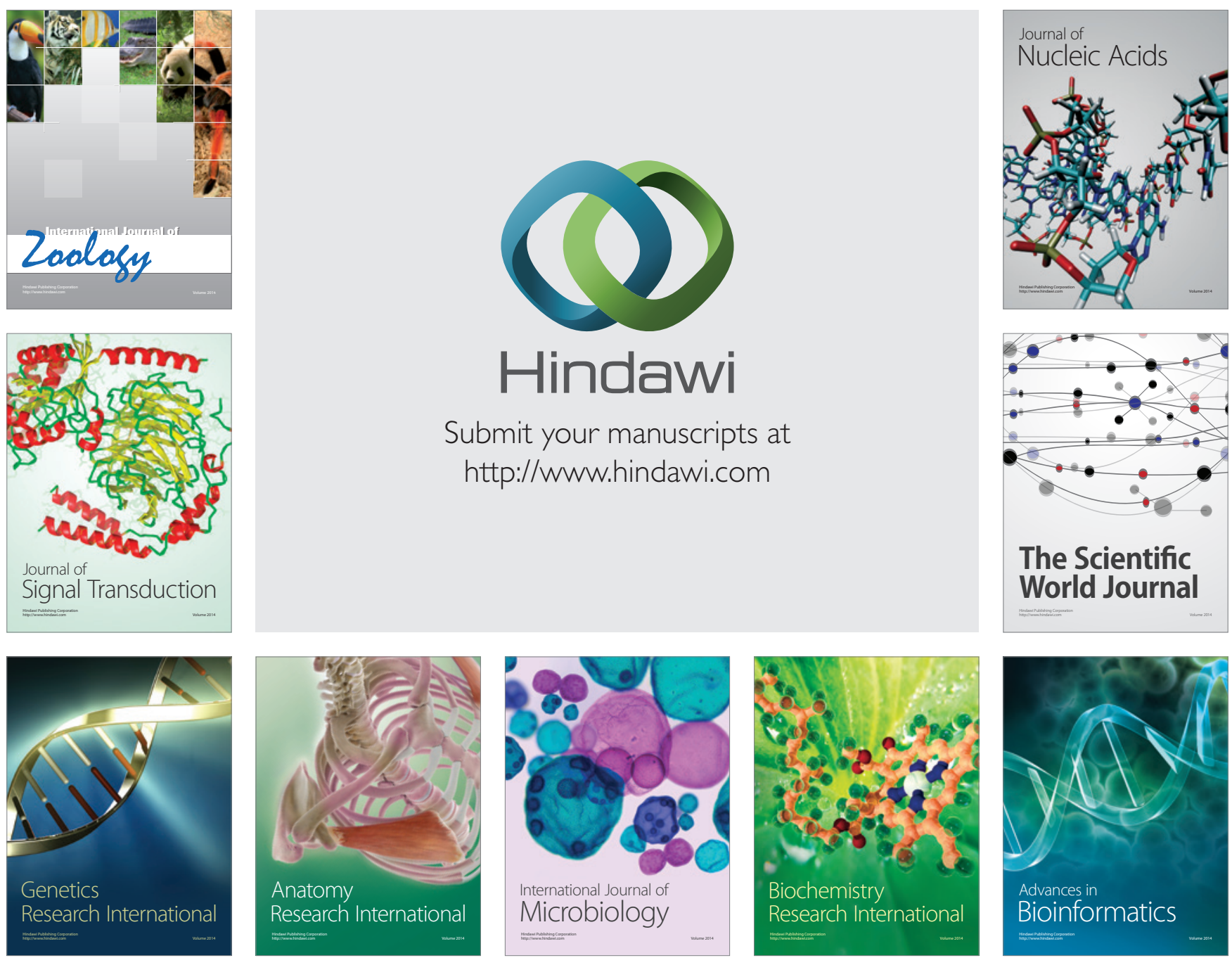

The Scientific World Journal
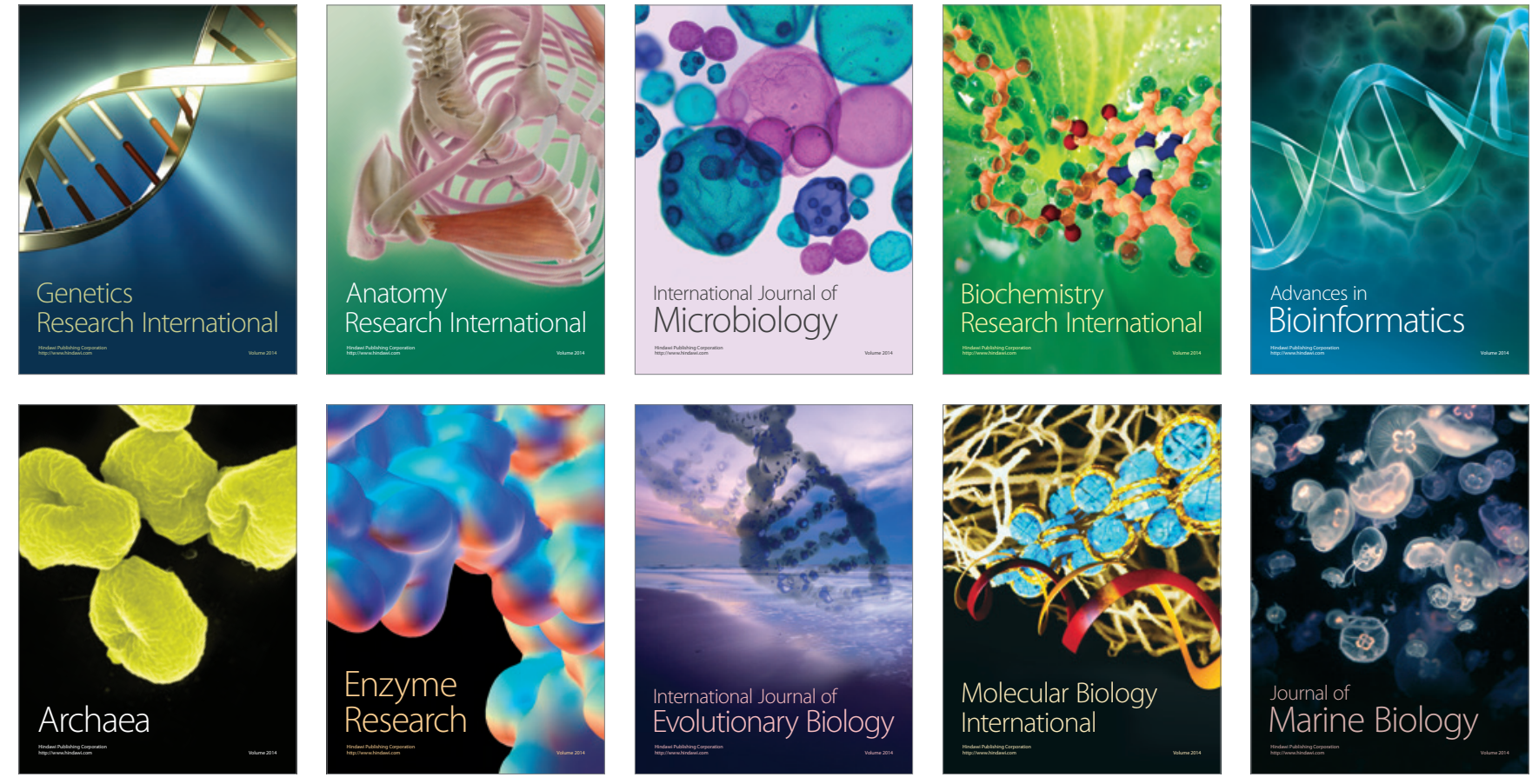